\title{
DOSE RATE EFFECT OF PULSED ELECTRON BEAM ON MICRONUCLEUS FREQUENCY IN HUMAN PERIPHERAL BLOOD LYMPHOCYTES
}

\author{
Santhosh ACHARYA ${ }^{1}$, Ganesh SANJEEV ${ }^{1}$, Nagesh N. BHAT ${ }^{2}$, and Yerol NARAYANA ${ }^{1}$ \\ Microtron Centre, Department of Studies in Physics, Mangalore University, Mangalagangotri', \\ Radiological Physics and Advisory Division, Bhabha Atomic Research Centre, Mumbai², India \\ Received in June 2009 \\ Accepted in October 2009
}

\begin{abstract}
The micronucleus assay in human peripheral blood lymphocytes is a sensitive indicator of radiation damage and could serve as a biological dosimeter in evaluating suspected overexposure to ionising radiation. Micronucleus (MN) frequency as a measure of chromosomal damage has also extensively been employed to quantify the effects of radiation dose rate on biological systems. Here we studied the effects of $8 \mathrm{MeV}$ pulsed electron beam emitted by Microtron electron accelerator on MN induction at dose rates between $35 \mathrm{~Gy} \mathrm{~min}^{-1}$ and $352.5 \mathrm{~Gy} \mathrm{~min}^{-1}$. These dose rates were achieved by varying the pulse repetition rate (PRR). Fricke dosimeter was employed to measure the absorbed dose at different PRR and to ensure uniform dose distribution of the electron beam. To study the dose rate effect, blood samples were irradiated to an absorbed dose of $(4.7 \pm 0.2)$ Gy at different rates and cytogenetic damage was quantified using the micronucleus assay. The obtained MN frequency showed no dose rate dependence within the studied dose rate range. Our earlier dose effect study using $8 \mathrm{MeV}$ electrons revealed that the response of MN was linear-quadratic. Therefore, in the event of an accident, dose estimation can be made using linear-quadratic dose response parameters, without adding dose rate as a correction factor.
\end{abstract}

KEY WORDS: dosimetry, microtron, $8 \mathrm{MeV}$ electrons, pulse repetition rate

The micronucleus (MN) assay has been suggested as a reliable alternative method to scoring chromosome aberrations such as dicentrics and rings $(1,2)$. It allows for the screening of much larger numbers of cells. Furthermore, MN in cytokinesis-blocked binucleated lymphocytes have been used to quantitatively assess the absorbed dose in cases of suspected radiation exposure and situations involving radiation accidents (3). The dose-response curve of $\mathrm{MN}$ frequency in peripheral blood lymphocytes induced by low linearenergy-transfer (LET) radiations is best described by linear-quadratic function (4-7). The slope of the dose-response curve, which represents a numerical measure of aberrations induced by single radiation track events, is usually independent of the dose rate.
The quadratic component that refers to an interaction between effects from two or more independent tracks is dose rate dependent, and its magnitude depends on the time interval between the two tracks (8).

The dose rate effect of radiation is a biophysical phenomenon and is a consequence of repair of sublethal damage. Several earlier studies have suggested that even though it is quite obvious that radiobiological damage decreases with the dose rate, this does not work the other way around when the dose rate rises above a certain level $(5,9-11)$. However, there are conflicting reports regarding the dose rate effect studied in different types of cells (12-15).

Our earlier dose-effect study using $8 \mathrm{MeV}$ electrons revealed that the response of $\mathrm{MN}$ was linear-quadratic 
in nature (16). Since the quadratic (b) coefficient of the dose-response curve is dose-rate-dependent and dose assessment is done using dose-response parameters, it is essential to have data for a wide range of dose rates, particularly those encountered in the working environment. These are most relevant for radiological protection and for understanding the biophysical aspect at different dose rates in biological dosimetry. Furthermore, it is well understood that dose rate must be considered when evaluating radiation risks (17). Information is not available in literature on the effect of dose rate on the induction of $\mathrm{MN}$ in human peripheral blood lymphocytes exposed to $8 \mathrm{MeV}$ pulsed electron beam in the average dose rate range of $35 \mathrm{~Gy} \mathrm{~min}^{-1}$ to $352.5 \mathrm{~Gy} \mathrm{~min}^{-1}$ at an instantaneous dose rate of $2.6 \times 10^{5} \mathrm{~Gy} \mathrm{~s}^{-1}$ (dose per pulse is $0.6 \mathrm{~Gy}$ and pulse width is $2.3 \mu \mathrm{s}$ ). Therefore, the aim of this study was to establish MN yield induced at different dose rates of the $8 \mathrm{MeV}$ electron beam. We hoped to obtain useful results that would help to correct the quadratic coefficient of the dose-response curve previously obtained for $8 \mathrm{MeV}$ electrons. We also assumed that the results would be relevant for radiotherapy.

\section{MATERIAL AND METHODS}

\section{Blood sampling}

Whole blood was collected in a heparinised vial by veinpuncture from a healthy 27 -year-old male donor without any history of radiation exposure. The blood was stored at $4{ }^{\circ} \mathrm{C}$ immediately after collection for half an hour.

\section{Dosimetry}

Radiation doses administered to blood samples were measured using the Fricke dosimeter. Electron beam current was measured using a fast current transformer (FCT) and the corresponding electron numbers were counted using a current integrator $(\mathrm{CI})$. The number of electrons in the CI was calibrated against the absorbed dose using the Fricke dosimeter. Dosimetry was carried out at $30 \mathrm{~cm}$ from the beam exit point of the accelerator at room temperature $\left(25^{\circ} \mathrm{C}\right)$. It also served to calibrate $\mathrm{CI}$ reading against the absorbed dose for different PRR and to establish the area with uniform dose distribution at sample position. At $30 \mathrm{~cm}$ from the beam exit point uniform dose distribution was established on a field sized
$4 \mathrm{~cm} \mathrm{x} 4 \mathrm{~cm}$, which is similar to an earlier report with a ferrous sulphate-benzoic acid-xylenol orange dosimeter (18). The field size was measured in water phantom at $3 \mathrm{~cm}$ depth (18).

\section{Irradiation}

The source of high dose rate electron beam was a pulsed mode circular Microtron accelerator at Mangalore University, India. The machine can provide maximum pulse current of $50 \mathrm{~mA}$ with pulse width of $2.5 \mu$ s (for details see ref. 19). In this study, $1 \mathrm{~mL}$ blood samples were exposed to an average dose of (4.7 \pm 0.2$)$ Gy at different dose rates in an identical geometry as that of dosimeter. Just like dosimeters, samples were irradiated at the distance of $30 \mathrm{~cm}$ from the electron beam exit point. Figure 1 shows a photograph of the accelerator with a schematic diagram of irradiation set up. During irradiation, dose per pulse was kept constant and exposure times changed according to PRR to achieve the desired absorbed dose. The pulse lasted $2.3 \mu$ s and the mean dose per pulse was $0.6 \mathrm{~Gy}$, which corresponds to a mean dose rate of $2.6 \times 10^{5} \mathrm{~Gy} \mathrm{~s}^{-1}$.

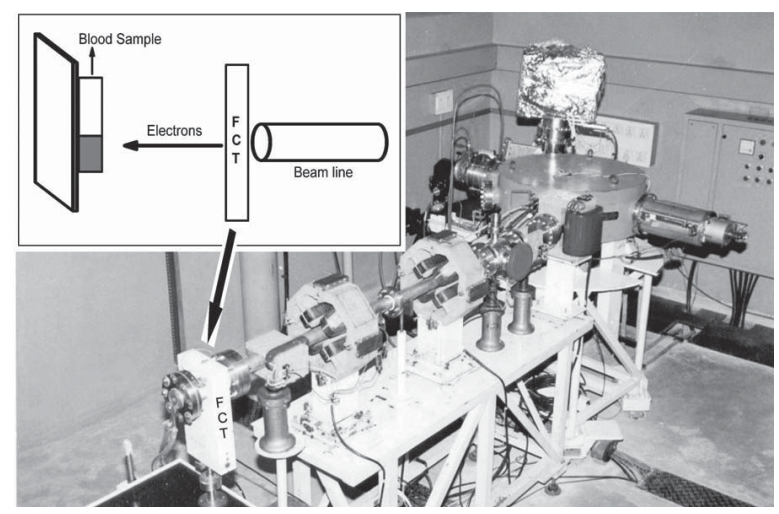

Figure 1 Photograph of Microtron accelerator with a schematic diagram of the irradiation setup.

\section{Culturing and processing technique}

The MN assay was performed as described by Fenech and Morley (20) with a few modifications. After irradiation, $1 \mathrm{~mL}$ blood samples were cultured with $9 \mathrm{~mL}$ of RPMI-1640 (Sigma, USA) medium supplemented with $20 \%$ foetal calf serum (Sigma, USA) and phytohaemagglutinin (Sigma, USA). The cells were cultivated in sterile disposal culture tubes in an incubator at $37^{\circ} \mathrm{C}$. Cytochalasin-B $\left(5 \mu \mathrm{g} \mathrm{mL}{ }^{-1}\right.$, Sigma, USA) was added after $44 \mathrm{~h}$ of incubation to block cytokinesis. Cultures were harvested at $70 \mathrm{~h}$ and treated with a mild hypotonic solution for $6 \mathrm{~min}$. The 
cells were fixed with a fixative containing a mixture of acetic acid, $0.9 \% \mathrm{NaCl}$, and methanol (6:12:13, respectively) for 6 min and washed three times by centrifugation with a fixative containing acetic acid and methanol (1:4). Finally, the cell pellets were mixed gently with about $0.5 \mathrm{~mL}$ of fixative and spread on clean cold slides. The slides were stained with a $0.125 \%$ solution of acridine orange and observed using a fluorescent microscope with a FITC filter under 400x magnification. Only binucleated cells surrounded by cytoplasm and cell membrane were eligible for scoring $\mathrm{MN}$ using the criteria described by Heddle (21). Cells with two fused nuclei or with broken cytoplasm were ignored. Binucleated cells containing one or more $\mathrm{MN}$ were noted separately.

\section{Statistical analysis}

MN distribution in irradiated lymphocytes was analysed using the Papworth's $u$-test (22). Positive and negative $u$ value indicates overdispersion and underdispersion, respectively, in respect to perfect Poisson's distribution $(u=0)$. If the value of $u$ is greater than \pm 1.96 , then the dispersion is significant at $95 \%$ confidence level (23).

The results were statistically processed and the significance was estimated using the Student's $t$-test (one sample $t$-test). Differences were considered significant at $\mathrm{p}<0.05$.

\section{RESULTS}

No variation in the absorbed dose was observed when the dose was given at different PRR (Figure 2). Each data point represents the average of four measurements.

Figure 3 shows the electron dose distribution in the horizontal and vertical plane at $30 \mathrm{~cm}$ distance from the beam exit window, measured using the Fricke dosimeter. We evaluated the $4 \mathrm{~cm} \mathrm{x} 4 \mathrm{~cm}$ field with uniform dose distribution keeping within the $95 \%$ confidence limit. The dosimetry standard was compliant with national standards and the physical variables such as dose rate and dose per pulse used in this study were within the limit of Fricke dosimeter (24).

Table 1 shows the total exposure time and time gaps between the pulses, corresponding to the number of PRR. Total exposure time in each case was calculated using the average dose $(0.6 \mathrm{~Gy})$ per pulse

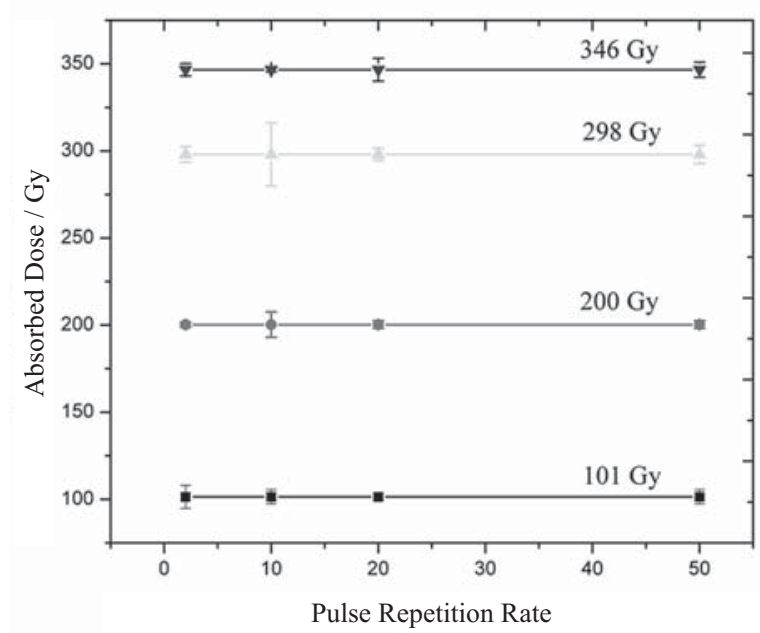

Figure 2 Measurements of absorbed dose at different pulse repetition rate using the Fricke dosimeter. Error bar indicates standard deviation.

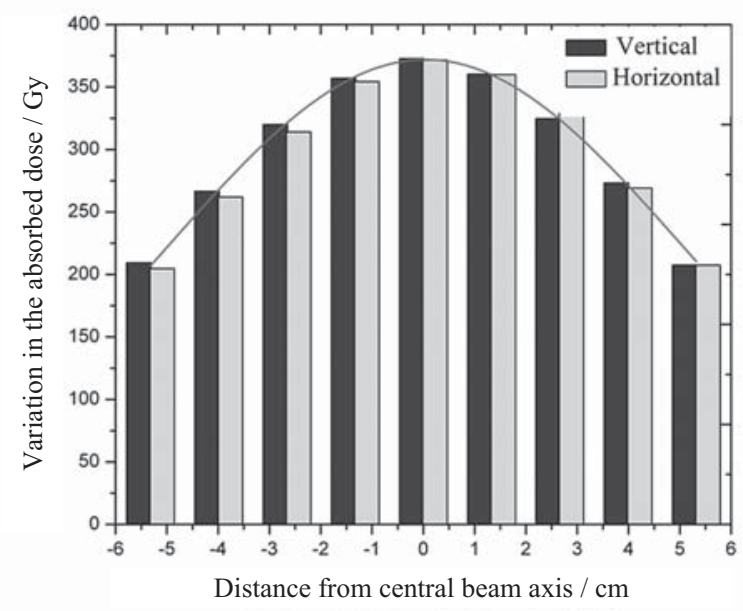

Figure 3 Dose profile for electron beam in horizontal and vertical planes at $30 \mathrm{~cm}$ distance from the beam exit window.

and the corresponding number of pulses used per

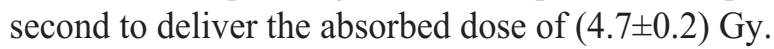
The average dose rate was calculated by dividing absorbed dose with the total exposure time. The time gap between the pulses was also calculated.

Table 2 shows the distribution of MN in binuclear cells and their yield by average dose rates. As the dose per pulse is not constant, minor variation in the values was expected (see Table 1). For all the dose rates used we observed underdispersion with respect to the Poisson distribution. The results clearly show that $\mathrm{MN}$ yield induced at different dose rates did not significantly differ $(\mathrm{p}=0.58, \mathrm{t}=0.60, \mathrm{DoF}=4)$. 
Table 1 The conditions of irradiation

\begin{tabular}{lccc}
\hline PRR & $\begin{array}{c}\text { Average dose rate / } \\
\text { Gy } \text { }^{-1}\end{array}$ & Total exposure time / s & $\begin{array}{c}\text { Time gap between } \\
\text { the pulses / s }\end{array}$ \\
\hline 1 & 35.0 & 8 & 0.99 \\
\hline 2 & 70.5 & 4 & 0.49 \\
\hline 4 & 141.0 & 2 & 0.25 \\
\hline 5 & 176.3 & 1.6 & 0.19 \\
\hline 10 & 352.5 & 0.8 & 0.09 \\
\hline
\end{tabular}

$P R R$ is the pulse repetition rate

Mean instantaneous dose rate during irradiation was $2.6 \times 10^{5} \mathrm{~Gy} \mathrm{~s}^{-1}$

Table $2 M N$ distribution and yield at different electron beam radiation dose rates

\begin{tabular}{|c|c|c|c|c|c|c|c|c|c|c|c|}
\hline \multirow{2}{*}{$\begin{array}{l}\text { Average } \\
\text { dose rates / } \\
\text { Gy } \text { min }^{-1} \\
\end{array}$} & \multicolumn{7}{|c|}{ No. of binucleated cells with } & \multirow{2}{*}{$\begin{array}{c}\text { Total } \\
\text { No. of } \\
\text { MN } \\
\end{array}$} & \multirow{2}{*}{$\begin{array}{l}\text { No. of } \\
\text { cells } \\
\text { scored }\end{array}$} & \multirow{2}{*}{$\mathrm{MN}$ yield $\pm \mathrm{SE}$} & \multirow[b]{2}{*}{$\boldsymbol{u}$} \\
\hline & $0 \mathrm{MN}$ & $1 \mathrm{MN}$ & $2 \mathrm{MN}$ & $3 \mathrm{MN}$ & $4 \mathrm{MN}$ & $5 \mathrm{MN}$ & $6 \mathrm{MN}$ & & & & \\
\hline 35.0 & 285 & 380 & 223 & 96 & 12 & 4 & 0 & 1182 & 1000 & $1.18 \pm 0.03$ & -2.84 \\
\hline 70.5 & 420 & 546 & 372 & 124 & 28 & 7 & 3 & 1827 & 1500 & $1.22 \pm 0.03$ & -2.55 \\
\hline 141.0 & 260 & 397 & 245 & 98 & 13 & 10 & 2 & 1295 & 1025 & $1.26 \pm 0.04$ & -2.46 \\
\hline 176.3 & 412 & 548 & 332 & 163 & 34 & 7 & 4 & 1896 & 1500 & $1.26 \pm 0.03$ & -1.23 \\
\hline 352.5 & 328 & 380 & 204 & 68 & 14 & 6 & 0 & 1078 & 1000 & $1.08 \pm 0.05$ & -1.18 \\
\hline
\end{tabular}

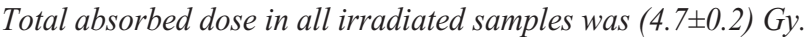
$\mathrm{u}$ is the dispersion index.

\section{DISCUSSION}

Micronucleus frequency in lymphocytes exposed to low LET radiation such X-rays, gamma rays, and electron beams increases linearly-quadratically with the absorbed dose, indicating a contribution of both single and multi-track lesions $(16,25,26)$. Therefore, MN frequency is clearly influenced by dose rates. However, MN frequency in lymphocytes exposed to pulsed electron beam at very high dose rates is low. In ultra-short pulse X-ray or electron irradiation, the effect at the molecular level involves a number of temporal sequences of physical, chemical, and biological events. In our study, temporal events did not influence the biological response as measured by MN frequency, either due to different ultra-high dose rates or due to changes in pulse frequency. Earlier studies of pulse irradiation are controversial, some reporting a decrease, and others increase or no variation in biological effects with dose rate $(12,27-30)$. Most of the earlier results suggest an increase in biological effects up to a dose rate of $1 \mathrm{~Gy} \mathrm{~min}^{-1}$ and no further increase unless doses were delivered in very short pulses. However, the cell survival study by Hornsey (15) suggests that the dose rate of $60 \mathrm{~Gy} \mathrm{~min}^{-1}$ is more damaging than $5 \mathrm{~Gy} \mathrm{~min}^{-1}$. The author suggested that dependence of sensitivity on dose rate was inherent to the cells rather than to radiation-induced change in the cell environment. Our wider dose rate range ( $35 \mathrm{~Gy} \mathrm{~min}^{-1}$ to $352.5 \mathrm{~Gy} \mathrm{~min}^{-1}$ ) has shown no dose rate effect on MN frequency, which is in agreement with results reported by Purrott et al., (10) for dicentrics at high dose rates.

As the dose rate increases in the ultra-high dose rate region, high radical concentration in a very short time can alter the probabilities of radical-radical and radical-target interactions, including the biological response. However, our study showed no influence of the dose rate on either radical recombination or radical accumulation that would alter MN frequency. Many studies have shown remarkable variation in biological damages with pulse frequency. Bellucci (31) showed that 20 pulses per second was the most lethal dose rate for cells in the pulse range of four to 24 pulses per second, while Hood and Norris (32) found no variations in lethality of normal and malignant human cells exposed to pulsed X-ray in the wide range of $1 \times 10^{5}$ to $3 \times 10^{5}$ pulses per minute. A significant depletion in oxygen concentration was demonstrated when doses were given in a single pulse. However, 
the same dose delivered in two pulses separated by $2 \mathrm{~ms}$ did not deplete oxygen (33). Pulse duration in our experiment is of the same order $(\mu \mathrm{s})$ as that used by Town (33), but the dose per pulse (45 Gy) used by Town was very high compared to the 0.6 Gy per pulse used in our study. High dose per pulse may influence cell micro environment and alter radiosensitivity, whereas small dose per pulse may not do so. This suggests that mean instantaneous dose rate may also affect radiation response.

In this study, the micronucleus assay was made on a blood sample collected from a single donor. However, detailed studies with blood samples of different donors are needed to understand the inter-donor dependence of $\mathrm{MN}$ frequency on dose rates.

Computer-controlled radiotherapy technology has encouraged investigation of pulsed dose rate as a replacement for conventional low dose rate treatment. In intensity-modulated radiation therapy, dose rate can be described by many physical variables like instantaneous dose rate, PRR, beam on time (pulse width) and delivery time (average dose rate), which requires a clear understanding of biological response to different physical variables (34).

\section{CONCLUSIONS}

Our study has shown no significant relation between $\mathrm{MN}$ frequency in lymphocytes and dose rates

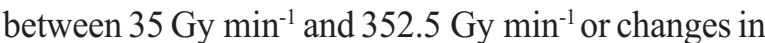
pulse frequencies from one to 10 pulses per second. This suggests that changing the off time in the electron pulses does not affect biological response. Those small variations we observed in $\mathrm{MN}$ frequencies/yields are well within the limits of statistical significance. Our present and earlier dose effect study suggests that in the event of an accident, the dose can be estimated using linear-quadratic dose-response parameters without adding a dose rate correction factor.

\section{Acknowledgements}

The authors are grateful to fellow researchers and technical staff at the Microtron Centre, Mangalore University for their help and support. The authors gratefully acknowledge the help and useful suggestions of Dr B S Rao, former head of the Radiological Physics and Advisory Division, Bhabha Atomic Research Centre, Mumbai. One of the authors, Santhosh Acharya acknowledges financial support by Board of Research in Nuclear Sciences and Department of Atomic Energy, Government of India.

\section{REFERENCES}

1. Fenech $\mathrm{M}$. The in vitro micronucleus technique. Mutat Res 2000;455:81-95.

2. Fenech M, Chang WP, Kirsch-Volders M, Holland N, Bonassi S, Zeiger E. Human project: detailed description of the scoring criteria for the cytokinesis-block micronucleus assay using isolated human lymphocyte cultures. Mutat Res 2003;534:65-75.

3. International Atomic Energy Agency (IAEA). Biological dosimetry: Chromosomal aberration analysis for dose assessment. Technical Reports Series no. 260. Vienna: IAEA; 1986.

4. Mill AJ, Wells J, Hall SC, Butler A. Micronucleus induction in human lymphocytes: comparative effects of X rays, alpha particles, beta particles and neutrons and implications for biological dosimeter. Radiat Res 1996;145:575-85.

5. Bhat NN, Rao BS. Dose rate effect on micronucleus induction in cytokinesis blocked human peripheral blood lymphocytes. Radiat Prot Dosim 2003;106:45-52.

6. Solomon FDP, Venkatachalam P, Jeevanram RK. Analysis of radiation dose response curve obtained with cytokinesis block micronucleus assay. Nucl Med Biol 1997;24:413-6.

7. Prosser JS, Moquet JE, Lloyd DC, Edwards AA. Radiation induction of micronuclei in human lymphocytes. Mutat Res 1988;199:37-45.

8. The dose response relationship obtained at constant irradiation times for the induction of chromosome aberrations in human lymphocytes by Cobalt-60 Gamma rays. Radiat Environ Biophys 1984:23:179-189.

9. Hall EJ, Brenner DJ. The dose-rate effect revisited: radiobiological considerations of importance in radiotherapy. Int J Radiat Oncol Biol Phys 1991;21:1403-14.

10. Purrott RJ, Reeder EJ, Lovell S. Chromosome aberration yields induced in human lymphocytes by $15 \mathrm{MeV}$ electrons given at a conventional dose-rate and in microsecond pulses. Int J Radiat Biol 1977:31:251-6.

11. Tillman C, Grafstrom G, Jonsson AC, Jonsson BA, Mercer I, Mattsson S, Strand SE, Svanberg S. Survival of mammalian cells exposed to ultrahigh dose rates from a laser-produced plasma X-ray source. Radiology 1999;213:860-5.

12. Shinohara K, Nakano H, Miyazaki N, Tago M, Kodama R. Effects of single pulse ( $\leq 1 \mathrm{ps}$ ) X-rays from laser-produced plasmas on mammalian cells. J Radiat Res 2004;45:50914.

13. Berry RJ, Hall EJ, Forster DW, Storr TH, Goodman MJ. Survival of mammalian cells exposed to X-rays at ultra high dose rates. Br J Radiol 1969;42:102-7.

14. Prempree T, Michelsen A, Merz T. The repair time of chromosome breaks induced by pulsed X-rays of ultra high dose rate. Int J Radiat Biol 1969;15:571-4.

15. Hornsey S. Differences in survival of jejunal crypt cells after radiation delivered at different dose rates. Br J Radiol 1970;43:802-6.

16. Acharya S, Ganesh S, Bhat NN, Siddappa K, Narayana $Y$. The effect of electron and gamma irradiation on the induction of micronuclei in Cytokinesis-blocked human blood lymphocytes. Radiat Environ Biophys 2009;48:197203.

17. Sinclair WK. The linear no-threshold response: why not linearity? Med Phys 1998;25:285-90. 
18. Gupta BL, Narayan GR, Nilekani SR, Bhat RM, Kaul A, Bemalkhedkar MM, Soni HC, Ganesh S, Nagesh YN, Prashant KC, Umakanth D, Gnana Prakash AP, Siddappa K. Preliminary dosimetry studies for microtron using chemical dosimeter. J Radiat Prot Environ 1999;22:169-74.

19. Siddappa K, Ganesh S, Balakrishna KM, Ramamurthi SS, Soni HC, Shrivastava P, Sheth Y, Hemnani R. Variable energy microtron for R \& D work. Radiat Phys Chem 1998;51:441-2.

20. Fenech M, Morley AA. Measurement of micronuclei in lymphocytes. Mutat Res 1985;147:29-36.

21. Heddle JA. A rapid in vivo test for chromosomal damage. Mutat Res 1973;18:187-90.

22. Papworth DG. Appendix to paper by Savage JRK. Sites of radiation induced chromosome exchanges. Curr Top Radiat Res 1970;6:129-94.

23. Edwards AA, Lloyd DC, Purrott RJ. Radiation induced chromosomal aberrations and the Poisson distribution. Radiat Environ Biophys 1979;116:89-100.

24. International Commission on Radiation Units and Measurements (ICRU). The dosimetry of pulsed radiation (Report 34). Washington (DC): ICRU; 1983.

25. Bhat NN, Rao BS. Dose rate effect on micronuclei induction in cytokinesis blocked human peripheral blood lymphocytes. Radiat Prot Dosim 2003;106:45-52.
26. Kormos C, Köteles GJ. Micronuclei in X-irradiated human lymphocytes. Mutat Res 1988;199:31-5.

27. Deveaux LC, Wells DP, Hunt A, Webb T, Beezhold W, Harmon JF. Accelerator-based radiation sources for nextgeneration radiobiological research. Nucl Instrum Method Phys Res Sec A 2006;562:981-4.

28. Epp ER, Weiss H, Santomasso A. The oxygen effect in bacteria cells irradiated with high intensity pulsed electrons. Radiat Res 1968;34:320-5.

29. Hall EJ. Radiation dose rate: a factor of importance in radiobiology and radiotherapy. Br J Radiol 1972;45:81-97.

30. Hornsey S, Alper T. Unexpected dose rate effect in the killing of mice by radiation. Nature 1966;210:212-3.

31. Bellucci M. Modifications in the biological effect of $\mathrm{X}$-radiation with respect to the rhythmic fractionation of the radiation beam. Radioterap Radiobiol E Fiz Med 1960;14:188-204.

32. Hood SL, Norris G. Human cell survival after pulsed Xirradiation. Radiat Res 1965;24:81-7.

33. Town CD. Effects of high dose rates on survival of mammalian cells. Nature 1967;215:847-8.

34. Bewes JM, Suchowerska N, Jackson M, Zhang M, McKenzie DR. The radiobiological effect of intra-fraction dose-rate modulation in intensity modulated radiation therapy (IMRT). Phys Med Biol 2008;53:3567-78. 


\section{Sažetak \\ UTJECAJ BRZINE DOZE PULSNOGA ZRAČENJA NA NASTANAK MIKRONUKLEUSA U LIMFOCITIMA PERIFERNE LJUDSKE KRVI}

Mikronukleus-test pokazao se osjetljivim pokazateljem oštećenja u limfocitima periferne ljudske krvi te se primjenjuje kao biološki dozimetar posumnja li se na prekomjerno izlaganje ionizirajućem zračenju. Mikronukleusi kao mjera oštećenja kromosoma često se rabe za procjenu učinaka zračenja u biološkim sustavima. Ovdje je istraženo djelovanje pulsnoga elektronskoga snopa od $8 \mathrm{MeV}$, dobivenog s pomoću elektronskoga akceleratora marke Microtron, na nastanak mikronukleusa u rasponu brzina doza od $35 \mathrm{~Gy} \mathrm{~min}^{-1}$ do $352.5 \mathrm{~Gy} \mathrm{~min}^{-1}$. Brzine doza mijenjale su se mijenjajući brzinu ponavljanja pulsa (tzv. pulse repetition rate, krat. PRR). Za mjerenje apsorbirane doze pri različitim PRR-ovima rabio se Frickeov dozimetar. Dozimetrijska su mjerenja također poslužila za ujednačavanje doze elektronskoga snopa.

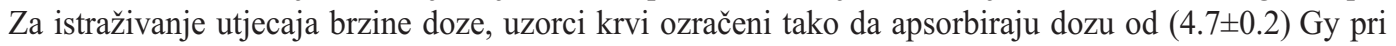
različitim brzinama doze, a zatim se s pomoću mikronukleus-testa utvrdilo citogenetsko oštećenje. Pokus s pulsnim snopovima energije $8 \mathrm{MeV}$ upućuje na neovisnost broja mikronukleusa o brzinama doze u rasponu ispitanome u ovom istraživanju. Naše ranije istraživanje utjecaja doze pulsnoga elektronskoga zračenja energije $8 \mathrm{MeV}$ upozorilo je na linearni do kvadratni odgovor izmjerenih parametara. Stoga se akcidentalna doza može procijeniti s pomoću linearnih do kvadratnih parametara odgovora na dozu, bez potrebe za korekcijom s pomoću brzine doze.

KLJUČNE RIJEČI: akcelerator, dozimetrija, elektronski snop, PRR

\section{CORRESPONDING AUTHOR:}

Yerol Narayana

Microtron Centre

Mangalore University, Department of Studies in Physics

Mangalagangotri-574 199, Karnataka, India

E-mail:narayanay@yahoo.com 